\title{
Dormancy Breaking and Germination Requirements of Nimble Will (Muhlenbergia schreberi Gmel.) Seeds
}

\author{
JERRY M. BASKIN AND CAROL C. BASKIN
}

\section{Abstract}

Nimble will (Muhlenbergia schreberi Gmel.), a native perennial $C_{4}$ grass, is a serious weed in horse pastures in the Bluegrass Region of Kentucky. This study investigated the dormancy breaking and germination requirements of this species. Seeds mature in October, are dispersed mostly during autumn and winter, and germinate in spring. Seeds were dormant at maturity, but they became nondormant during (1) dry storage in the laboratory, (2) 99 days of incubation on moist sand at $35 / 20^{\circ} \mathrm{C}$, or (3) cold stratification. Germination percentages were higher in light than in darkness, and cold stratified seeds germinated to higher percentages than drystored seeds. Seeds sown in a nonheated greenhouse in autumn were cold stratified during winter, and they germinated in spring when temperatures became nonlimiting. However, seeds that remained on the parent plants in the field over winter did not gain the ability to germinate at spring temperatures $\left(20 / 10^{\circ} \mathrm{C}\right)$ by spring. Under some test conditions, the intact palea and lemma inhibited germination, but under other conditions they were not inhibitory.

Nimble will (Muhlenbergia schreberi Gmel.) is a native warmseason or $\mathrm{C}_{4}$ (Bender 1971 , Hattersley and Watson 1976) perennial grass whose geographical range extends from southern Ontario and New England to northern Florida, westward to Iowa and central Texas (Pohl 1969, Dore and McNeill 1980). The original habitat of the species was light shade of moist forests (Pohl 1969), but it also now is common in lawns, waste places, and other disturbed habitats (Pohl 1969, Swink and Wilhelm 1979). Nimble will is the weediest species in the subgenus Muhlenbergia (Pohl 1969), and Holm et al. (1979) list it as a common weed in the USA. In Kentucky the species is a weed in pastures and hay crops (Palmer 1979). However, aside from general information given in various taxonomic works, only a few scattered references on this species have been found in the literature.

Nimble will is a serious problem in horse pastures in the Bluegrass Region of Kentucky, where Kentucky bluegrass (Poa pratensis L.) is the preferred grass (J.K. Evans, pers. comm.). The species is unpalatable to horses, and thus its presence decreases the grazing quality of the bluegrass pastures. Additionally, nimble willinfested pastures are unsightly from autumn to spring, when the species shows up as dead patches of grass in the bluegrass sod.

In view of the importance of nimble will as a weed in horse pastures in central Kentucky and the paucity of information on the species, we are undertaking a study of its life cycle biology. This paper reports on the dormancy breaking and germination requirements of nimble will seeds. A knowledge of when seeds germinate and what environmental factors break dormancy and promote germination will aid in planning a successful management strategy for this species.

Nimble will is a hemicryptophyte (Ennis 1928, McDonald 1937, Gibson 1961) with weak, slender sprawling culms that fall over and root at the nodes. The plants lack true stolons or rhizomes. In July, buds are initiated at the basal nodes of the culms. These buds give rise to new culms, which grow to a length of 1 to $5 \mathrm{~cm}$ by the beginning of winter. The new culms remain green during winter but do not elongate. Growth of the culms resumes in early spring, and by July they are fully elongated. Plants flower in August and

\footnotetext{
Authors are professor and adjunct associate professor, School of Biological Sciences, University of Kentucky, Lexington $40506-0225$.

This project was financed in part with funds from the United States Department of Agriculture under grants number 71-59-2481-1-2-039-1 and 82-CRSR-2-1000.

Manuscript accepted March 25, 1985.
}

September, and seeds are mature by late October. Seeds remain attached to the mother plant at maturity, and most of them are dispersed during autumn and winter.

\section{Methods}

The first objective was to determine when nimble will seeds would germinate in a nonheated greenhouse, where temperatures were near those out-of-doors (Baskin and Baskin 1981). Mean daily maximum and minimum weekly temperatures for the duration of the study were calculated from continuous thermograph records. Freshly matured caryopses (hereafter called seeds) were collected on 21 October 1981, and 7 days later 3 replications of 300 seeds each with the palea and lemma (hulls) intact were sown on soil in small flats. The soil was watered daily, except when frozen in winter, until the study was terminated on 18 May 1982. The flats were examined for seedlings at 7-day intervals.

Objective two was to test the temperature and light requirements for germination of seeds exhumed after 0 to 12 months of burial in soil. Seeds were collected on 21 October 1981, and 7 days later about 3,000 were placed in cach of 12 fine-mesh nylon bags. Each bag was buried to a depth of $7 \mathrm{~cm}$ in soil in a $15-\mathrm{cm}$-diameter clay pot. The pots were kept in the nonheated greenhouse and watered daily, except when frozen. Germination tests were conducted on fresh seeds and on those that had been buried for 1 to 4 months. We originally planned to exhume seeds each month until November 1982. However, many of the buried seeds germinated in the soil in March 1982, so the experiment was terminated. Germination tests were performed in incubators at a 14-h photoperiod (ca. $20 \mu \mathrm{mol}$ $\left.\mathrm{m}^{-2} \mathrm{~s}^{-1}, 400-700 \mathrm{~nm}\right)$ and in constant darkness at $(12 / 12 \mathrm{~h})$ alternating temperature regimes of $15 / 6,20 / 10,25 / 15,30 / 15$, and $35 / 20^{\circ} \mathrm{C}$. Seeds were incubated on moist sand in $5.5-\mathrm{cm}$ petri dishes. For dark-incubated seeds, 3 dishes of 50-75 seeds were placed at each temperature, and for light-incubated seeds 3 dishes of 50 seeds were used. Dishes incubated in darkness were wrapped with 2 layers of aluminum foil, and all manipulations of dark-incubated seeds were carried out in total darkness. Germination percentages were determined after 15 days.

Objective three was to determine the effects of cold stratification on germination of seeds with and without hulls. Seeds were collected on 7 November 1982, and studies were initiated 4 days later. Seeds were placed on moist sand in $5.5-\mathrm{cm}$ petri dishes, and 3 replications of 50 seeds each were used for each treatment. Seeds with and without hulls were given 3,6 , and 9 weeks of cold stratification at $5^{\circ} \mathrm{C}$ in light (14-h daily photoperiod, $20 \mu \mathrm{mol} \mathrm{m}$ $\mathrm{s}^{-1}, 400-700 \mathrm{~nm}$ ) and then tested in light at 15/6,20/10,25/15, $30 / 15$, and $35 / 20^{\circ} \mathrm{C}$. Also seeds stratified for 12 weeks in light were incubated in light and darkness at the 5 thermoperiods, and those stratified for 12 weeks in darkness were incubated in light and darkness. Germination percentages were determined after 15 days of incubation. In one set of controls, fresh seeds with and without hulls were placed in light and darkness at the 5 thermoperiods. After 15 days the seeds were examined, and those tested in darkness were discarded. Seeds tested in light were kept at their respective incubation temperatures until the experiment was terminated 12 weeks later. They were examined at 15-day intervals. In the second control, seeds with and without hulls were placed in closed bottles in the laboratory ( $\mathrm{ca} 22-25^{\circ} \mathrm{C}$ ). After 3, 6, 9, and 12 weeks of storage, seeds were incubated in light for 15 days at the 5 thermoperiods. After 12 weeks of storage, seeds also were tested in darkness at all thermoperiods. Germination percentages of seeds 
with and without hulls at each test condition were compared using Student's $t$-test at the $5 \%$ level of significance.

Objective four was to determine if seeds that remain on the parent plant all winter become nondormant. On 23 March 1982, seeds produced in 1981 were collected from plants in the field, and their germination with and without hulls was compared to that of seeds stored dry with and without hulls in the laboratory since 21 October 1981. Seeds were incubated in light and darkness for 15 days at the 5 thermoperiods. The least significant difference for all germination percentages at each thermoperiod was computed using Tukey's Honestly Significant Difference test (HSD) at the $5 \%$ level of significance.

\section{Results and Discussion}

Freshly matured seeds of nimble will were dormant and thus did not germinate in light or darkness at any thermoperiod (Fig. Ic, d).

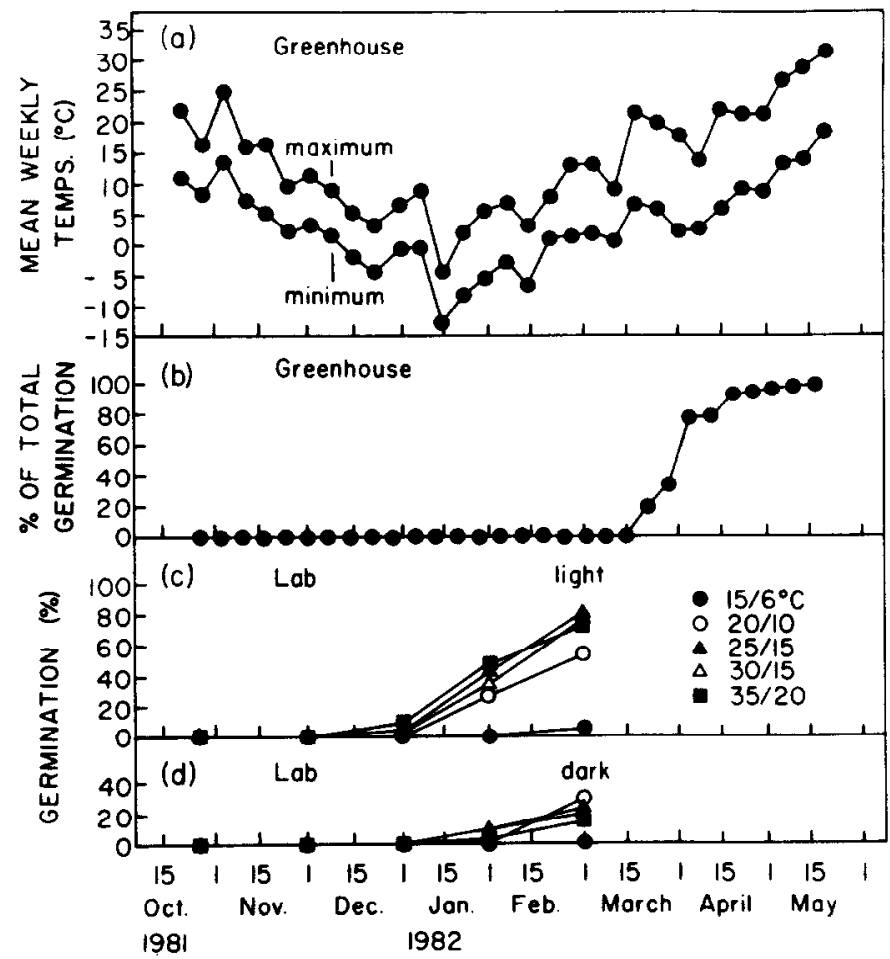

Fig. 1. Germination of nimble will seeds. (a) Mean daily maximum and minimum weekly air temperatures in the nonheated greenhouse. (b) Germination of seeds planted on soil in the greenhouse. (c) Germination of freshly matured seeds and those buried in soil in the greenhouse for 1 to 4 months and exhumed on 1 December, 1 January, 1 February, and 1 March. Seeds were incubated at a 14-h photoperiod at 5 thermoperiods. (d) Germination of freshly matured seeds and of those exhumed on 4 dates and incubated in darkness at 5 thermoperiods.

During winter, seeds exposed to natural temperatures in the nonheated greenhouse lost their dormancy (afterripened). Seeds sown on soil in the greenhouse in October began to germinate in mid March and continued to germinate until mid May (Fig. lb). A total of $349(39 \%)$ of the 900 seeds germinated. The peak of germination occurred between 15 March and 5 April, when mean daily maximum and minimum temperatures were 19.5 and $5.5^{\circ} \mathrm{C}$, respectively (Fig. la). In March, exhumed seeds germinated to 5, 54, 82, 77 , and $73 \%$ in light at $15 / 6,20 / 10,25 / 15,30 / 15$, and $35 / 20^{\circ} \mathrm{C}$, respectively, and to $0,31,20,24$, and $16 \%$, respectively, in darkness (Fig. Ic, d). Since seeds exhumed on 1 March germinated to $31 \%$ at $20 / 10^{\circ} \mathrm{C}$ in darkness, it is not surprising that many buried seeds germinated in the nonheated greenhouse during March.

Seeds of nimble will do not require cold stratifiction to afterripen (Fig. 2). Control seeds with and without hulls kept on moist

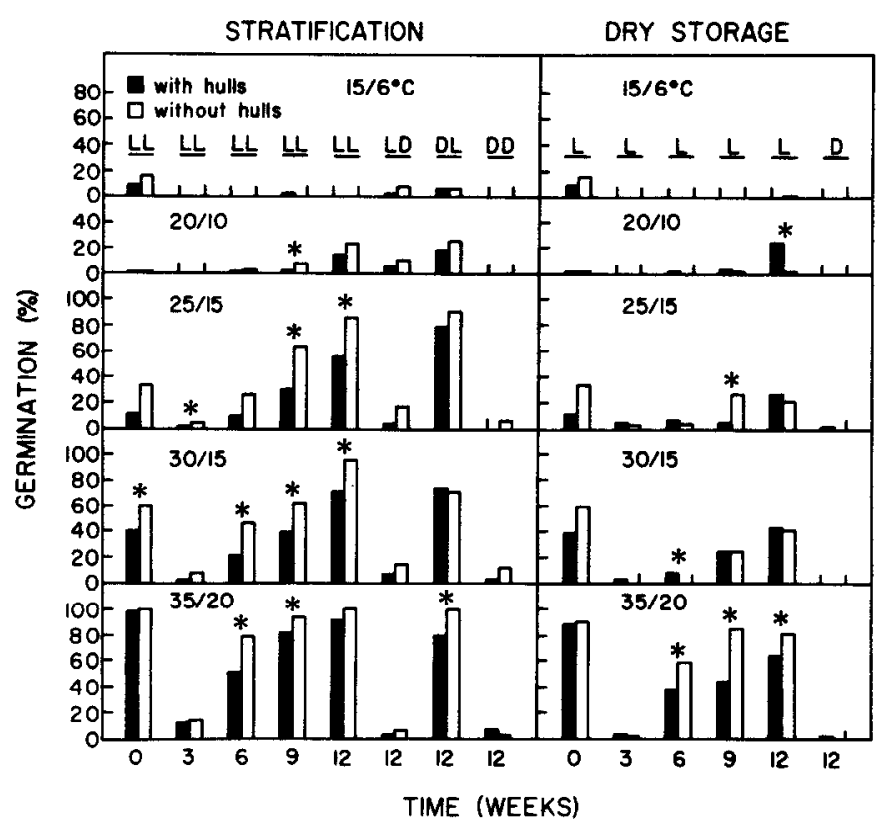

Fig. 2. Germination after 15 days of incubation in light at 5 thermoperiods of nimble will seeds with (shaded bars) and without (open bars) hulls following 0 to 12 weeks of cold stratification or dry storage. The 0-week controls remained at the thermoperiods for 99 days; no seeds had germinated after 15 days. Seeds stratified for 12 weeks in light or darkness were incubated in both light $(L L, D L)$ and darkness $(L D, D D)$. = significant at the 5\% level using Student's t- test.

sand at $35 / 20^{\circ} \mathrm{C}$ germinated to 99 and $100 \%$, respectively, during the 99-day incubation period. Also, seeds with and without hulls stored dry in the laboratory for 12 weeks germinated to 65 and $81 \%$, respectively, at $35 / 20^{\circ} \mathrm{C}$ in light. However, with only 3 exceptions, at $20 / 10$ and $25 / 15^{\circ} \mathrm{C}$, seeds with and without hulls stratified for $3,6,9$, and 12 weeks at $5^{\circ} \mathrm{C}$ germinated to higher percentages at all thermoperiods than seeds with and without hulls stored dry in the laboratory for $3,6,9$, and 12 weeks. Light was required for a high percentage of the seeds to germinate, and light given during stratification did not promote germination of seeds subsequently incubated in darkness. For each treatment and control, germination percentages of seeds incubated in light tended to increase with temperature.

Since most nimble will seeds are dispersed in autumn and winter, they are cold stratified during winter. Thus, they are nondormant by early spring and germinate when temperatures become nonlimiting. Seeds that were not dispersed during autumn and winter germinated to only $5 \%$ at spring $\left(20 / 10^{\circ} \mathrm{C}\right)$ temperatures in spring (Table 1). In order for seeds to be cold stratified, they must be imbibed, so undispersed seeds must have been dry (non imbibed) for much of the winter.

Nimble will seeds without hulls germinated to a significantly higher percentage than those with hulls in 14 of the 70 laboatory tests (Fig. 2). In many species of grasses, the presence of hulls has been shown to inhibit germination by restricting the diffusion of gases (Vose 1965, Mott 1974, Renard and Capelle 1976), mechanically restricting embryo growth (Andersen 1953, Martin 1975) and the presence of inhibitory chemicals (Ahring, Eastin and Garrison 1975, Renard 1976, Kato et al. 1977). Under some test conditions hulls were inhibitory to germination in nimble will, while under other test conditions there was no significant difference in germination of seeds with and without hulls. The role of hulls in regulating germination of this species in the field is unknown. However, hulls were still on the seeds of nimble will that germinated in the nonheated greenhouse.

Studies on the germination of sand muhly (Muhlenbergia are- 
Table 1. Germination percentages (mean \pm SE) of nimble will seeds that matured in 1981 . Seeds were tested after 0 (fresh) and 5 months of afterripening in dry storage in the laboratory and after 5 months on the dead, erect flowering culms in the field. Tukey's HSD for each thermoperiod is given at the foot of each column.

\begin{tabular}{|c|c|c|c|c|c|c|c|}
\hline \multirow[b]{2}{*}{ Treatment } & \multirow[b]{2}{*}{ Hulls } & \multirow[b]{2}{*}{ Light or dark } & \multicolumn{5}{|c|}{ Incubation temperatures $\left({ }^{\circ} \mathrm{C}\right)$} \\
\hline & & & $15 / 6$ & $20 / 10$ & $25 / 15$ & $30 / 15$ & $35 / 20$ \\
\hline \multirow[t]{4}{*}{ Fresh } & present & light & 0 & 0 & $\mathbf{0}$ & 0 & 0 \\
\hline & present & dark & 0 & 0 & 0 & 0 & 0 \\
\hline & absent & light & 0 & 0 & 0 & 0 & 0 \\
\hline & absent & dark & 0 & 0 & 0 & 0 & 0 \\
\hline \multirow[t]{4}{*}{ Dry storage } & present & light & $11 \pm 3$ & $64 \pm 5$ & $84 \pm 3$ & $94 \pm 1$ & $97 \pm 1$ \\
\hline & present & dark & $1 \pm 1$ & $1 \pm 1$ & $2 \pm 0$ & $4 \pm 2$ & $1 \pm 1$ \\
\hline & absent & light & $62 \pm 2$ & $61 \pm 2$ & $83 \pm 5$ & $99 \pm 1$ & $95 \pm 2$ \\
\hline & absent & dark & $1 \pm 1$ & $1 \pm 1$ & $2 \pm 2$ & $3 \pm 1$ & $1 \pm 1$ \\
\hline \multirow[t]{4}{*}{ Field } & present & light & 0 & $5 \pm 1$ & $11 \pm 2$ & $25 \pm 2$ & $60 \pm 1$ \\
\hline & present & dark & 0 & $1 \pm 1$ & 0 & $3 \pm 1$ & $15 \pm 3$ \\
\hline & absent & light & 0 & $7 \pm 3$ & $24 \pm 3$ & $41 \pm 4$ & $57 \pm 6$ \\
\hline & absent & dark & 0 & $1 \pm 1$ & $1 \pm 1$ & $11 \pm 5$ & $12 \pm 3$ \\
\hline HSD & & & 4 & 11 & 12 & 12 & 13 \\
\hline
\end{tabular}

nicola Buckl.) (Jackson 1928), bushy muhly (M. porteri Scribn.) (Jackson 1928, Toole 1938, Ashley and Hellmers 1955, Knipe and Herbel 1966), upland wild timothy (M. racemosa (Michx.) B.S.P.) (Toole 1938), purple muhley (M. rigens (Benth.) Hitchc.) (Toole 1938) and spike muhly (M. wrightii Vasey) (Sabo et al. 1979) indicate that they germinate well at high $\left(20 / 30,20 / 35,25^{\circ} \mathrm{C}\right)$ temperatures, as do seeds of nimble will. In bushy muhly, purple muhly and upland wild timothy, 14 days of chilling had no effect on germination (Toole 1938). However, in none of these studies were freshly matured seeds tested to determine if they were dormant. In Jackson's (1928) study of bush muhly, 6-month-old seeds germinated to $75 \%$ at $25^{\circ} \mathrm{C}$. With this exception, the ages of all the other seeds in the various studies are unknown. Further, in none of these studies were the storage conditions of the seeds given. Thus, we must assume that seeds of these 5 species of Muhlenbergia were either nondormant at maturity, or, more likley, they were dormant at maturity and afterripened in dry storage, as do seeds of nimble will.

The fear by thoroughbred farm owners and managers that herbicides will do harm to their horses precludes the use of herbicides in most bluegrass pastures. Thus, control of nimble will is difficult. One place to start a management program that perhaps may lead to a significant decrease of nimble will in horse pastures would be to prevent germination in areas of a pasture where the sod is discontinuous. However, any seeds that are imbibed during winter will afterripen and germinate in spring, even though they may have become covered by soil during winter. Although seeds stratified at $5^{\circ} \mathrm{C}$ in darkness gave little or no germination in darkness at the 5 test thermoperiods (Fig. 2), those buried in soil and exposed to natural temperatures during winter germinated to $31 \%$ when exhumed and tested at spring $\left(20 / 10^{\circ} \mathrm{C}\right)$ temperatures in March (Fig. Id). Spread of the species by seeds in a pasture could be prevented by not allowing plants to set seeds. Close mowing during flowering in August and September should reduce the number of seeds produced. Further, fertilizing pastures during the cool season would enhance the early growth of bluegrass, and thus incease its competitiveness with both seedlings and established plants of nimble will in spring.

\section{Literature Cited}

Ahring, R.M., J.D. Eastin, and C.S. Garrison. 1975. Seed appendanges and germination of two Asiatic bluestems. Agron. J. 67:321-325.

Andersen, A.M. 1953. The effect of the glumes of Paspalum notatum Flugge on germination. Proc. Ass. Off. Seed Anal. 43:93-100.

Ashby, W., and H. Hellmers. 1955. Temperature requirements for germination in relation to wild-land seeding. J. Range Manage. 8:80-83.
Baskin, J.M., and C.C. Baskin. 1981. Seasonal changes in the germination responses of buried Lamium amplexicaule seeds. Weed Res. 21:299-306.

Bender, M. 1971. Variations in the ${ }^{13} \mathrm{C} /{ }^{12} \mathrm{C}$ ratios of plants in relation to the pathway of photosynthetic carbon dioxide fixation. Phytochemistry 10:1239-1244.

Dore, W.G., and J. McNeill. 1980. Grasses of Ontario. Research Branch, Agriculture Canada, Monogr. No. 26.

Ennis, B. 1928. The life forms of Connecticut plants and their significance in relation to climate. State Geol. and Nat. Hist. Surv. of Conn. Bull. No. 43 .

Gibson, D. 1961. Life-forms of Kentucky flowering plants. Amer. Mid. Natur. 66:1-60.

Hattersley, P., and L. Watson. 1976. $C_{4}$ grasses: An anatomical criterion for distinguishing between NADP-malic emzyme species and PCK or NAD-malic enzyme species. Aust. J. Bot. 24:294-308.

Holm, L., J.B. Pancho, J.P. Herberger, and D.L. Plucknett. 1979. A geographical atlas of world weeds. John Wiley and Sons, New York.

Jackson, C. 1928. Seed germination in certain New Mexico range grasses. Bot. Gaz. 86:270-294.

Kato, T., M. Tsunakawa, N. Sasaki, H. Aizawa, K. Fujita, Y. Kitahara, and N. Takahashi. 1977. Growth and germination inhibitors in rice husks. Phytochemistry 16:45-48.

Knipe, D., and C. Herbel. 1966. Germination and growth of some grassland species treated with aqueous extract from creosote bush. Ecology 47:775-781.

Martin, C.C. 1975. The role of glumes and gibberellic acid in dormancy of Themeda triandra spikelets. Physiol. Plant. 33:171-176.

McDonald, Sr. E.S. 1937. The life forms of the flowering plants of Indiana. Amer. Mid. Natur. 18:687-773.

Mott, J.J. 1974. Mechanisms controlling dormancy in the arid zone grass Aristida contorta. I. Physiology and mechanisms of dormancy. Aust. J. Bot. 22:635-645.

Palmer, R.D. 1979. Weed survey - Southern states. Res. Rep. South. Weed Sci. Soc. 32:111-136.

Pohl, R.W. 1969. Muhlenbergia, subgenus Muhlenbergia (Gramineae) in North America. Amer. Mid. Nat. 82:512-542.

Renard, C. 1976. Présence de composés phénoliques dans les enveloppes des épillets de Brachiaria ruziziensis Germain et Evrard. Bull. Soc. Roy. Bot. Belg. 109:227-230.

Renard, C., and P. Capelle. 1976. Seed germination in Ruzizi grass (Brachiaria ruziziensis Germain \& Evrard). Aust. J. Bot. 24:437-446.

Sabo, D.G., G.V.Johnson, W.C. Martin, and E.F. Aldon. 1979. Germination requirements of 19 species of arid land plants. USDA Forest Serv. Res. Pap. RM-210.

Swink, F., and G. Wilhelm. 1979. Plants of the Chicago region, 3rd ed. The Mortun Arboretum, Lisle, IL.

Toole, V. 1938. Germination requirements of the seed of some introduced and native range grasses. Proc. Ass. Off. Seed Anal. 30:227-243.

Vose, P.B. 1956. Dormancy of seeds of Phalaris arundinacea and Phalaris tuberosa. Nature 178:1006-1007. 